\title{
EARLY PROTEROZOIC METAMORPHOSED KIMBERLITES FROM GABON
}

\author{
Alwyn Henning*1 , Gail Kiviets ${ }^{2}$, Stephan Kurszlaukis ${ }^{2}$, Erika Barton ${ }^{2}$, and Francis Mayaga- \\ Mikolo ${ }^{1}$ \\ ${ }^{1}$ De Beers Prospecting Gabon, Gabon; ${ }^{2}$ De Beers GeoScience Centre, South Africa
}

\section{INTRODUCTION AND EXPLORATION HISTORY}

The Bureau de Recherches Géologiques et Minières (BRGM) discovered a number of ultramafic dykes in the Mitzic area of north-west Gabon in the late sixties. These were classified as meta-kimberlite by Bardet (1973) based on the presence of kimberlitic Cr-spinel, diamonds and a characteristic Rare Earth Element pattern. Other typical kimberlitic indicator minerals such as pyrope garnet, $\mathrm{Mg}$-ilmenite and $\mathrm{Cr}$-diopside are scarce or totally absent. Petrographically, the rocks show variable metamorphic grades reaching amphibolite-facies. Although the original kimberlitic mineralogy and texture has largely been destroyed as a result of the metamorphism, olivine relict structures are in many cases still present supporting the classification of these dykes as kimberlitic.

Since 1998 De Beers Africa Exploration has relocated these bodies as well as discovered a number of new ones.

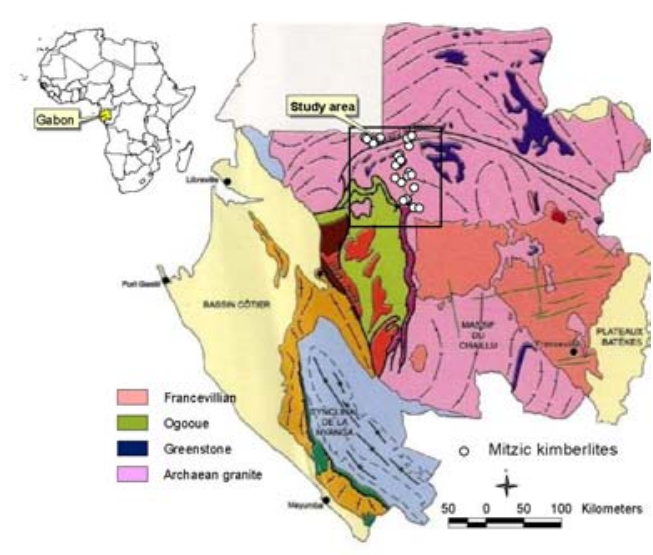

Figure 1: Locality map showing simplified geology for Gabon as well as the study area and the position of the Mitzic kimberlites.

\section{REGIONAL GEOLOGY}

The Archaean basement in the Mitzic area is a part of the North Gabon Massif, which forms part of the Congo craton (Figure 1). The Archaean basement in Gabon developed in 5 stages (Feybesse, et. al., 1998) as summarised in Table 1. The first stage consisted of the emplacement of the TTG, a banded gneiss older than 3.1 Ga. This was followed by the formation of

Table 1: Summary of the geologic evolution of the study area

\begin{tabular}{|c|c|c|c|c|c|c|c|c|c|}
\hline Ages (Ga) & $>3.1$ & 3.1 & $3.0-2.95$ & $2.95-2.8$ & $2.85-2.75$ & $2.75-2.7$ & $2.5-2.2$ & 2.15 & 1.0 \\
\hline Magmatism & $\begin{array}{l}\text { TTG } \\
\text { (banded } \\
\text { gneiss) }\end{array}$ & & & $\begin{array}{l}\text { Granitic to } \\
\text { tonalitic }\end{array}$ & $\begin{array}{l}\text { Dioritic to } \\
\text { granodioritic }\end{array}$ & $\begin{array}{l}\text { Late granitic; } \\
\text { Kimberlites } \\
(?)\end{array}$ & & & $\begin{array}{l}\text { Mafic } \\
\text { dykes }\end{array}$ \\
\hline Metamorphism & & $\begin{array}{l}\text { High- } \\
\text { grade } \\
\text { (gneiss) }\end{array}$ & & $\begin{array}{l}\text { High-grade to } \\
\text { medium } \\
\text { grade } \\
\text { (banded } \\
\text { gneiss \& BIF) }\end{array}$ & & $\begin{array}{l}\text { Medium- } \\
\text { grade? } \\
(2,725 \mathrm{Ma}) ; \\
\text { Low-grade? } \\
(2,700 \mathrm{Ma})\end{array}$ & & & \\
\hline $\begin{array}{l}\text { Tectonic } \\
\text { events }\end{array}$ & & $\begin{array}{l}\text { F1 } \\
\text { foliation } \\
\text { (banded } \\
\text { gneiss) }\end{array}$ & & $\begin{array}{l}\text { F2 foliation } \\
\text { affecting } \\
\text { gneiss \& BIF }\end{array}$ & & & $\begin{array}{l}\text { N'kol } \\
\text { fault? }\end{array}$ & $\begin{array}{l}\text { NW- } \\
\text { SE } \\
\text { fault? }\end{array}$ & \\
\hline Sedimentation & & & $\begin{array}{l}\text { Greenstone } \\
\text { belts } \\
\text { including } \\
\text { BIF }\end{array}$ & & & & & & \\
\hline
\end{tabular}


greenstone belts (BIF, metasediments and mafic and ultramafic igneous rocks) older than $3.0 \mathrm{Ga}$ structurally overlying the banded gneiss. In a later stage nonrotational deformation of the existing rocks occurred. Foliation developed under medium- to high-grade metamorphic conditions. A major granitic to tonalitic suite intruded the basement between 2950 and $2850 \mathrm{Ma}$ resulting in medium- to high-grade metamorphic deformation of the host rocks. Finally, between 2800 and $2500 \mathrm{Ma}$ the Kinguélé ultramafic rocks as well as leucogranite, syenogranite, monzogranite and granite commonly enriched in Th and U were emplaced.

The Archaean basement is unconformably or tectonically overlain by early Proterozoic rocks, namely the metavolcanic sedimentary deposits of the Ogooué orogenic domain (2235-2040 Ma) and the Francevillian volcano sediments (2150-1780 Ma).

\section{KIMBERLITE GEOLOGY}

Even though diamond occurrences are known quite widely on the Congo craton, the kimberlites in the Mitzic area are the only known primary sources. There has never been any exploitation of alluvial deposits in this area with the only diamond production coming from a small amount of alluvial activity in the south of Gabon in the Makongonio area.

Field relations suggest the presence of hypabyssal dykes often showing clear flow-alignment of olivine relict structures, i.e. aphanitic contact zones and more macrocrystic central zones. For some dykes a complex, multi-phase intrusion history is indicated. The bodies display a large variation in thickness and can be over $10 \mathrm{~m}$ wide in places. The dykes appear to be arranged in an en echelon system with a structural length of several tens of kilometres in a NW-SE strike orientation.

\section{PETROGRAPHY}

Petrographically, most kimberlite protoliths are classified as olivine macrocrystic, highly micaceous hypabyssal kimberlites. Depending on the sample, the olivine- and phlogopite abundances may be highly variable. Some samples show in excess of $50 \%$ modal olivine macro- and phenocryst content, while other samples consist almost entirely of phlogopite and do hardly show any evidence of olivine relicts. The latter, often highly micaceous rocks occur especially as finegrained contact facies along dyke margins. Otherwise there is no spatial relationship between the mineralogy and the location of the samples. The groundmass mineralogy of the kimberlites varies depending on the sample and can comprise talc, phlogopite, amphibole neoblasts (actinolite-tremolite and hornblende), spinel (and spinel-ilmenite intergrowths) as well as rare sulphides, epidote, tourmaline, ilmenite, serpentine, quartz, microcline, carbonate, biotite, clinopyroxene, chlorite, zircon, apatite, rutile, perovskite and sphene in variable degrees of alteration.

The metamorphic overprint spans from almost unmetamorphosed kimberlites over kimberlites of the greenschist facies to hornblende-rich rocks of the amphibolite facies. In spite of the extensive metamorphic overprint, olivine relict structures are often still identifiable (Figures 2 and 3). Depending of the sample and the degree of metamorphism, the olivines may either be replaced by serpentine, talc, phlogopite or amphibole.

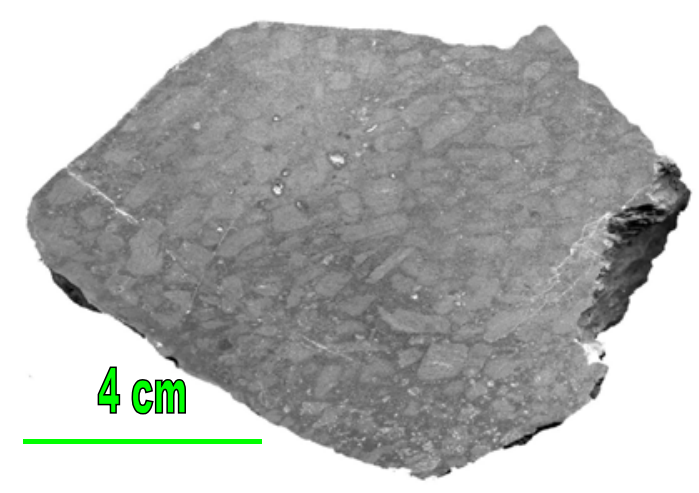

Figure 2: Sample EBB226: The steatitised hand specimen shows a high abundance of possible olivine macrocryst remnants in flow alignment.

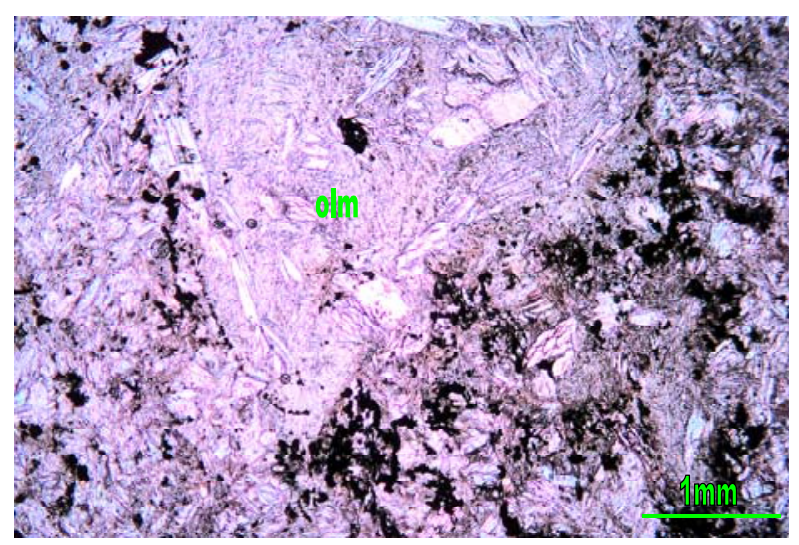

Figure 3: Sample EBB230: The top centre of the photograph is dominated by the amphibolitised pseudomorph of a possible olivine macrocryst (olm). Amphibolite of the actinolite-tremolite series comprises most of the remaining thin section. PPL. 
A schistose texture together with local shear indicators and microfolding is evident in the higher metamorphosed samples. The latter suggests that the dykes may have intruded along faults, which have been tectonically re-activated after intrusion of the kimberlites. However, there is no systematic difference in metamorphic grade with different strike directions, which might suggest several stages of intrusion in variable stress fields.

\section{WHOLE ROCK GEOCHEMISTRY}

Preliminary geochemical results indicate a whole rock geochemical signature typical of kimberlite. However, element migration may have played a role in the case of certain metamorphosed samples.

\section{GEOCHRONOLOGY}

Petrographic descriptions and whole rock geochemistry of two samples each from the Ayolo kimberlite (CRD967 and CRD968) and the Amie-02 kimberlite (CRD970 and CRD972) suggested that the rocks represented metamorphosed kimberlite dykes. ${ }^{40} \mathrm{Ar} /{ }^{39} \mathrm{Ar}$ laser probe analyses were undertaken on amphibole and biotite grains present in the samples in order to obtain metamorphic overprint ages.

Analytical results are summarised in Table 2. Uncertainties on calculated plateau and weighted-mean ages are quoted at two-sigma $(2 \sigma)$ standard deviation. Individual ${ }^{40} \mathrm{Ar} /{ }^{39} \mathrm{Ar}$ analyses were undertaken on four amphibole grains from sample CRD967. Three produced plateaux $(2 \sigma)$ with apparent ages of $2006 \pm$ $26 \mathrm{Ma}, 1986 \pm 32 \mathrm{Ma}, 1923 \pm 34 \mathrm{Ma}$ while the remaining grain produced a weighted-mean age of 1940 $\pm 80 \mathrm{Ma}$. The single amphibole grain analysed from sample CRD968 yielded a plateau age of $2006 \pm 28$ Ma.

Three amphibole grains were analysed from sample CRD970. Two grains produced plateau ages of $2615 \pm$ $34 \mathrm{Ma}$ and $2550 \pm 84 \mathrm{Ma}$. The remaining grains produced a discordant age spectrum attributed to minor recoil loss of ${ }^{39} \mathrm{Ar}_{\mathrm{K}}$ in response to alteration.

Individual step heating analysis of four biotite grains from sample CRD972 yielded copious amount of argon, with up to eleven analysis steps for one grain. The biotite produced apparent age plateaux of $2342 \pm 14$ Ma, $2346 \pm 19 \mathrm{Ma}, 2,381 \pm 79 \mathrm{Ma}$ and $2309 \pm 34 \mathrm{Ma}$, respectively.
The ${ }^{40} \mathrm{Ar}{ }^{39} \mathrm{Ar}$ ages are interpreted as reflecting the time of metamorphism and cooling of the Ayolo and Amie-02 kimberlites. The difference between the amphibole and biotite apparent ages for Amie-02 may reflect the difference in blocking temperature for these minerals or biotite crystallisation during slow cooling.

\section{Table 2. Summary of ${ }^{40} \mathrm{Ar} /{ }^{39} \mathrm{Ar}$ laser probe results for Ayolo and Amie-02.}

\begin{tabular}{|l|l|l|}
\hline Sample & Mineral & Age $\pm 2 \sigma$ error (Ma) \\
\hline $\begin{array}{l}\text { CRD967 } \\
\text { (Ayolo) }\end{array}$ & Amphibole & $\begin{array}{l}2006 \pm 26 \mathrm{Ma} \text { (Plateau) } \\
1923 \pm 34 \mathrm{Ma} \text { (Plateau) } \\
1940 \pm 80 \mathrm{Ma}\end{array}$ \\
\hline $\begin{array}{l}\text { CRD968 } \\
\text { (Ayolo) }\end{array}$ & Amphibole & $2006 \pm 28 \mathrm{Ma}$ (Plateau) \\
\hline $\begin{array}{l}\text { CRD970 } \\
\text { (Amie-02) }\end{array}$ & Amphibole & $2615 \pm 34 \mathrm{Ma}$ (Plateau) \\
\hline $\begin{array}{l}\text { CRD972 } \\
\text { (Amie-02) }\end{array}$ & Biotite & $2,550 \pm 84 \mathrm{Ma}$ \\
& & $2342 \pm 14 \mathrm{Ma}$ (Plateau) \\
& & $2309 \pm 34 \mathrm{Ma}$ (Plateau) \\
\hline
\end{tabular}

Zircons were extracted from 6 kimberlite occurrences $(6,13,11,9,5$, and 17). The zircon xenocrysts were larger than those typically associated with crustal rocks. Two zircon populations are apparent. Group A, characterised by euhedral morphology and high $\mathrm{U}$ contents $( \pm 1000 \mathrm{ppm})$ is consistent with derivation from a crustal source. These grains yielded isotopic compositions that were too discordant to give any reliable indication of their primary age. Group B, characterised by anhedral (non-prismatic) shapes and moderate to low $\mathrm{U}$ and $\mathrm{Th}$ contents, is considered typical for zircon derived from a mantle source. The majority of zircons have $U$ contents of about $50 \mathrm{ppm}$. The zircons from occurrence 17 have a significantly higher average $U$ content of about $260 \mathrm{ppm}$. U contents of this magnitude are more common than initially postulated for mantle derived zircon (e.g. Kinny and Meyer, 1994; Barton et al., 1995). Trace element analysis and cathodoluminescent imaging is in progress to confirm the inferred mantle origin for the Group B zircon grains.

$\mathrm{U}-\mathrm{Pb}$ analyses using the LA-ICP-MS technique on 22 Group B zircon grains yields a weighted mean average ${ }^{207} \mathrm{~Pb} /{ }^{206} \mathrm{~Pb}$ age (not within error) of $2848 \pm 8 \mathrm{Ma}(2 \sigma$; MSWD $=9.2$ ). Linear regression of these 22 analyses indicates an upper intercept age of $2862 \pm 9 \mathrm{Ma}$, within error of the weighted average, and a lower intercept consistent with recent $\mathrm{Pb}$ loss (Figure 4). 


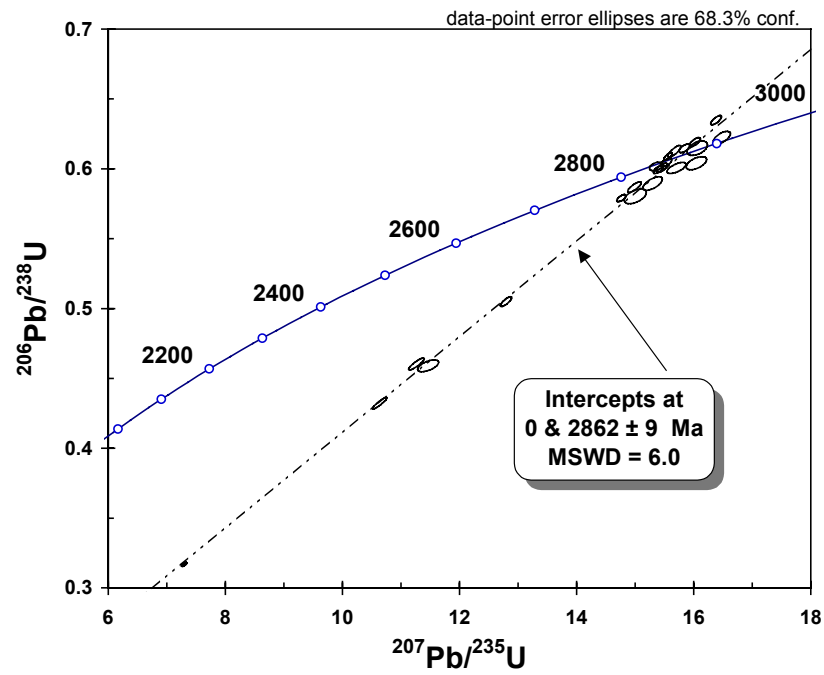

Figure 4: Concordia diagram illustrating the isotopic compositions of 22 zircon grains classified as Group B extracted from six kimberlite occurrences.

Assuming closure of the U-Pb system in the zircon is synchronous with the host rock emplacement, the age of $\pm 2850 \mathrm{Ma}$ is interpreted to reflect the time of emplacement of these kimberlite occurrences. The minimum ${ }^{40} \mathrm{Ar} /{ }^{39} \mathrm{Ar}$ ages of \pm 2600 to $\pm 2000 \mathrm{Ma}$ for amphibole and biotite from the Ayolo and Amie-02 occurrences supports this conclusion.

\section{CONCLUSIONS}

The Mitzic occurrences can be considered proper kimberlites based on the presence of Mg-ilmenite, Crspinel and diamonds. The petrography and whole rock chemistry corroborates this statement. There appears to be no spatial control on metamorphic grade or the phlogopite content of the bodies. The emplacement of the kimberlite bodies is structurally controlled with a general NW-SE strike direction. The age of $2850 \mathrm{Ma}$ would make these the oldest kimberlites known on earth. These kimberlites most likely originated from depleted lithosphere representing melting in the garnet lherzolite field supporting that the old lithosphere was not different from today's.

\section{REFERENCES}

Bardet, M.G., 1973. Geologie du Diamant. Memoires du BRGM, No. 83, 213-221

Barton, E.S., Brakhfogel, F.F., Williams, I.S., 1995. U-Pb zircon age for carbonatite and alkali-picrite pipes, Orto-Yiarga Field (Yakutia), Russia. Ext. Abstracts, 6th. Int. Kimb. Conf. Novosibirsk, Russia, pp. 37.

Kinny, P.D., Meyer, H.O.A., 1994. Zircon from the mantle: a new way to date old diamonds. Jour. Geol. 102, 475481.

Feybesse, J.L., Johan, V., Triboulet, C., Guerrot, C. MayagaMikolo, F., Bouchot, V., Eko N'Dong, J., 1998. The West Central African belt: a model of 2.5-2.0 Ga accretion and two-phase orogenic evolution. Precambrian Research. 87, 161-216.

Shee, S.R., Vercoe, S.C., Wyatt, B.W., Hwang, P.H., Campbell, A.N., Colgan, E.A., 1999. Discovery and Geology of the Nabberu Kimberlite Province, Western Australia. In: Proc. VII Int. Kimberlite Conf.. Cape Town, South Africa. Gurney, J.J, Gurney, J.L, Pascoe, and Richardson, S.H, (Eds.). National Book Printers, Goodwood, South Africa, pp 764-772.

Contact: A. Henning, PO Box 7383, Centurion 0046, South

Africa, E-mail: alwyn.henning@debeersgroup.com 